\title{
ADAPTATION OF URBAN USES OF ENVIRONMENTAL CHARACTERISTICS: A CASE STUDY OF LA SAFOR, VALENCIA, SPAIN
}

\author{
VICENT-JESÚS ALTUR-GRAU ${ }^{1}$, JESÚS-ANTONIO AGUILAR-MALDONADO ${ }^{1}$, \\ MARIA-TERESA SEBASTIÁ-FRASQUET ${ }^{1} \&$ JOSÉ LUIS MIRALLES I GARCIA $^{2}$ \\ ${ }^{1}$ Institut d'Investigació per a la Gestió Integrada de Zones Costaneres, Universitat Politècnica de València, Spain \\ ${ }^{2}$ Departament d'Urbanisme, Universitat Politècnica de València, Spain
}

\begin{abstract}
In the 1990s a methodology was developed to apply the concept of land aptitude to urban plans. This methodology was based on the concepts of capacity and vulnerability in the face of different urban uses (e.g. residential use, industrial use and strategic facilities). The methodology was implemented thanks to geographical information systems (GIS) mapping of available cartography. In recent years, the available cartography has increased in quantity and in spatial resolution. Also, urban planning and environmental legislation have evolved. In this study, we propose a methodological update to incorporate all these changes. The updated methodology is applied to La Safor (Valencia, Spain), which is a region composed of 31 municipalities. La Safor is a model case study because of its characteristics that makes it representative of both coastal and inner areas. Our results point out the need to incorporate legal constraints to the methodology. Including climate adaptation is also essential for strategic urbanism and to accomplish environmental requirements. The methodology presented can be defined as an integrated assessment tool necessary for sustainable development and minimizing environmental risks.
\end{abstract}

Keywords: urban planning, GIS, cartography, risk, vulnerability.

\section{INTRODUCTION}

This work is based on the method developed for assessing the aptitude of the territory to urban uses by the research team, UDR F. Eiximenis, Universitat Politècnica de València in 1996. This method was a result of a Collaboration Agreement with the Department of Public Works, Urban Planning and Transport of the Generalitat Valenciana (regional government). In 2013, the European Commission sent a communication to the European Parliament in order to introduce Green Infrastructure concept in Regional Policy. Regional government of Valencia develop this concept in last law about urban and regional planning, specifically in Regional and Urban Planning and Landscape Act of 2014. The current planning and territorial policy in Valencia establish the need to identify green infrastructure as a first step in the urban planning processes. So, the original method needs to be improved to have into account the green infrastructure constraints which are detailed in the methodology section [1].

The territorial organization of the Spanish State establishes a division of administrative competences between the different territorial levels: central state, regions, provinces and municipalities. The matters of land management, urban planning and environment that appear in this article correspond basically to regional governments. The regulatory provisions that this institution establishes for adequate urban growth in harmony with the proper protection of the environment, determine the need to develop methodologies such as the one presented here.

The present proposal of methodology is thought for its application in the whole territory of the Valencian Community. The administrative competences in Territorial Planning, Urbanism and Housing are vested in the Regional Government, in accordance with Article 
148.3 of the Spanish Constitution [2] and Article 49.9 of the Statute of Autonomy of the Valencian Community [3].

In the article 28.4 "Land Classification" of the Law of Territorial Planning, Urbanism and Landscape of the Comunitat Valenciana (LOTUP) [4] it is established that the classification as land for development by a plan supposes the aptitude of the lands for its urbanization, under previous programming. The object of the present methodology is to constitute a tool in the process of analysis, diagnosis and territorial and urban planning to fulfil the purpose of the Law: "... the regulation of the Valencian territory, of the urbanistic activity and of the use of the land for its rational use in accordance with its social function, as well as the strategic environmental and territorial evaluation of plans and programs" [4, article 1]. This article presents the methodological improvements that are incorporated as a result of the progress in the contents of the Territorial Information Systems and the progressive incorporation of new regulations.

\section{METHODOLOGY}

\subsection{Study area}

The methodology is tested on La Safor region, south of Valencia (Fig. 1). La Safor is in contact with the Mediterranean Sea, it has almost $30 \mathrm{~km}$ of coast, and important tourist urbanizations arranged in narrow strips parallel to the beaches. The territory is constituted by a coastal alluvial plain surrounded by a mountainous interior with peaks of up to $1,000 \mathrm{~m}$ above sea level in the Safor peak. The valleys are crossed by fluvial courses, which transport water from the interior to the coast. The Serpis River is the only fluvial course of regional scope that runs through the region. In the coastal alluvial plain, geological formations alternate, forming the morphology of glacis, marshes and sandbars on which most urban centres and crops settle.

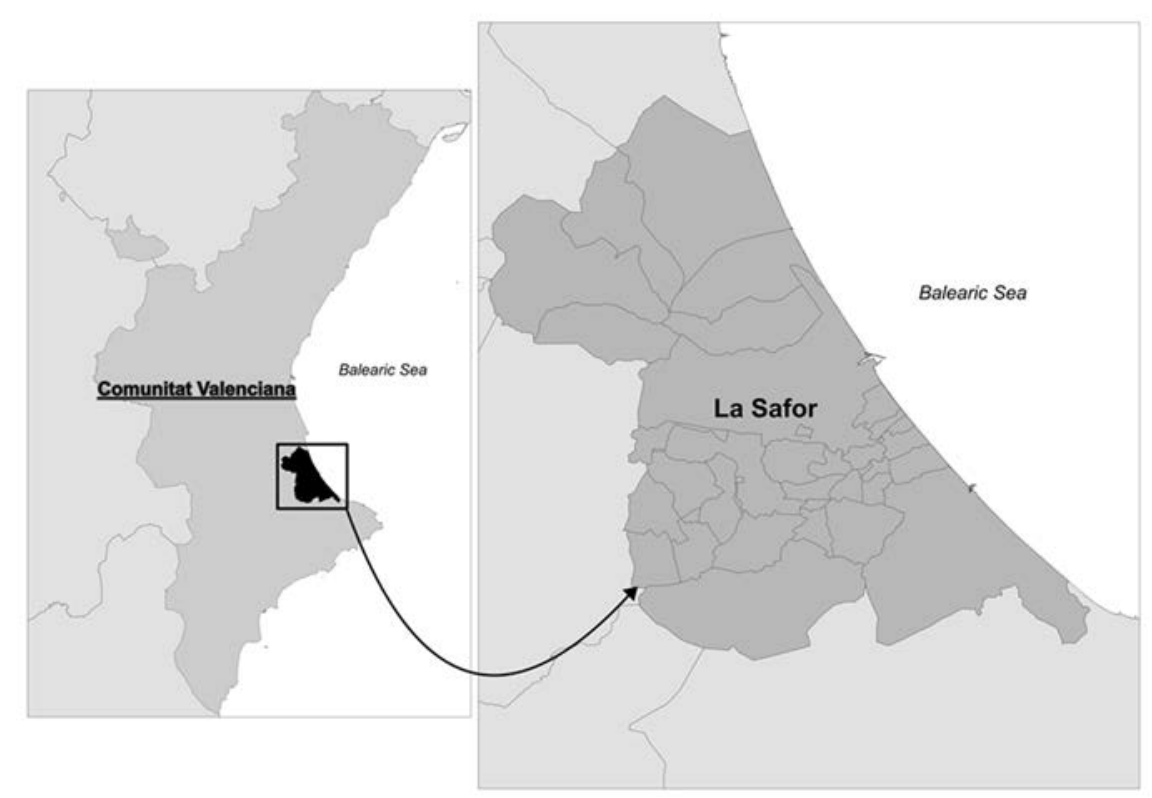

Figure 1: Study area location: La Safor (Valencia, Spain) and its municipal limits. 
The region has 31 municipalities divided into two subregions, the Valldigna and the Huerta de Gandia. Most of the population resides in the most important municipalities of Gandia, Oliva, Tavernes and Xeraco, where $80 \%$ of the total is concentrated, around 170,000 inhabitants in the whole of La Safor. Regarding the predominant uses, highlights the forest use with more than $50 \%$ of the county area, followed by agricultural uses dominated by citrus with more than $40 \%$. The rest of the uses are distributed among urban, infrastructure and equipment. The region has important protected areas from the environmental point of view: protected natural areas, Natura 2000 network, wetlands, micro-reserves, etc. These areas cover not only forest areas, but also important agricultural areas. Together they represent almost $30 \%$ of the total area of the region. The main economic activities in the region are tourism, the agro-food industry, agriculture, transport and services.

The physical and economic configuration of the region is very similar to that presented by the whole Valencian region. For this reason, it has been decided to use this administrative unit as a pilot test of the methodology of adaptation of the physical and natural environment to the potential urban uses.

The urban uses that are included in the present methodology have been synthesized in the following:

1. Urban general use (UG):

- Low and high density residential: $\leq 100$ homes per hectare.

- Tertiary.

- Industry: warehouses and workshops compatible with residential use.

- Non-strategic equipment: sports, socio-cultural, markets, green areas, etc.

- Camping areas.

- Others.

2. Industry, warehouses and workshops (I) with a unit occupation greater than 1 hectare, isolated and incompatible with residential use. Activities classified as annoying, unhealthy, harmful or dangerous.

3. Strategic equipment (EE): health, safety, administrative, sports and educational.

The three types of urban use considered raise, with regard to the characteristics of the physical environment, different answers and therefore the cartographies of capability, vulnerability and aptitude that are developed will serve as orientation in each of the cases.

In the present study, the analysis of the capability, vulnerability and aptitude will be developed for the urban general use (UG) since it is the most common in the surroundings of La Safor region. The other two urban uses are scarcer.

All the steps described next were performed using a geographic information system (GIS), specifically ArcGIS 10.3. The main cartographic source is the Valencian Spatial Data Infrastructure. This infrastructure is part of the Spanish Spatial Data Infrastructure (IDEE) and in turn to the European Spatial Data Infrastructure, legally developed in the European Inspire Directive [5] and incorporated into the Spanish legal system through the LISIGE [6]. This infrastructure complies with a series of standards and specifications that regulate and guarantee the interoperability of geographic information, such as ISO/TC211Geographic Information and EN CEN/TC 287.

In recent years, the IDE have been progressively providing new cartographic coverage that has been incorporated into this methodological application such as digital elevation models, forest plans or new infrastructures. In other cases, new versions of existing coverage have been published with higher cartographic quality (greater scale of detail and greater 
precision in the delimitation of polygons and paths) that improve the results obtained. For example, the topographic map in vector version allows the individual selection of variables which was not possible before. Also, the flood risk maps in the Valencian Region (PATRICOVA) has been updated. In this update, Flood Hazard and Flood Risk have been identified. The first refers to the probability that a given area will be flooded, and the second to the material damage that may occur in case of flooding. The scale detail has increased from 1:50,000 to $1: 25,000$, therefore the delimitation of the limits of the polygons is more adjusted to reality. Another example is the updated of protected natural areas limits. Their previous cartography and their internal zoning raised serious doubts when confronted with reality. In the first versions, the limits of natural areas were drawn by hand on the topographic map at a scale of 1:50,000, and were then digitized. The resulting coverage showed significant mismatches when overlapped with maps or orthophotos on a larger scale. In the new coverage, the limits are based on the cadastral coordinates and polygons related in the protection decrees. Therefore, the limits are much more exact. All these improvements of the cartographic database can be added to the methodology without a substantial change in the processes applied.

\subsection{Global capability}

Land capability to urban uses, as the appropriateness of the ground as a physical support for different urban uses [1].

Capability refers to the technical difficulties that the territory may present to the implementation of the different urban uses. To build global capability four cartographic variables were considered: terrain slope, geological risk, flood risk and accessibility to water resources. Table 1 explains the source of these cartographic vectors.

Table 1: Source of cartographic vectors for capability.

\begin{tabular}{|l|l|l|l|}
\hline $\begin{array}{l}\text { Cartographic } \\
\text { vector }\end{array}$ & $\begin{array}{l}\text { Download } \\
\text { server }\end{array}$ & $\begin{array}{l}\text { Creative institution } \\
\text { of the information }\end{array}$ & Observations \\
\hline $\begin{array}{l}\text { 1. } \\
\text { Slopes }\end{array}$ & $\begin{array}{l}\text { Valencian } \\
\text { Spatial Data } \\
\text { Infrastructure }\end{array}$ & $\begin{array}{l}\text { Valencian } \\
\text { Cartographic } \\
\text { Institute }\end{array}$ & $\begin{array}{l}\text { Layer created from the digital } \\
\text { model of the raster terrain of } \\
\text { 2 m pixel generated from } \\
\text { LiDAR flight of 0.5 points per } \\
\mathrm{m}^{2}\end{array}$ \\
\hline $\begin{array}{l}\text { Geological } \\
\text { risk }\end{array}$ & $\begin{array}{l}\text { Valencian } \\
\text { Spatial Data }\end{array}$ & $\begin{array}{l}\text { Ministry of } \\
\text { Infrastructure, } \\
\text { Territory and } \\
\text { Environment }\end{array}$ & $\begin{array}{l}\text { Information of the areas } \\
\text { affected by landslide and } \\
\text { landslide risks (polygons) for } \\
\text { the Valencian Community } \\
\text { (year 1991) }\end{array}$ \\
\hline $\begin{array}{l}3 . \\
\text { Flood risk }\end{array}$ & $\begin{array}{l}\text { Spatial Data } \\
\text { Infrastructure }\end{array}$ & $\begin{array}{l}\text { Ministry of } \\
\text { Infrastructure, } \\
\text { Territory and } \\
\text { Environment }\end{array}$ & $\begin{array}{l}\text { Flood risks on a regional scale } \\
\text { for the Valencian Community } \\
\text { (year 2015) }\end{array}$ \\
\hline $\begin{array}{l}\text { 4. } \\
\text { Accessibility } \\
\text { to water } \\
\text { resources }\end{array}$ & $\begin{array}{l}\text { Valencian } \\
\text { Spatial Data } \\
\text { Infrastructure }\end{array}$ & $\begin{array}{l}\text { Ministry of } \\
\text { Infrastructure, } \\
\text { Territory and } \\
\text { Environment }\end{array}$ & $\begin{array}{l}\text { Potential accessibility to water } \\
\text { resources in the Valencian } \\
\text { Community (year 1995) }\end{array}$ \\
\hline
\end{tabular}


Table 2: Categorization of the variable "capability for urban use".

\begin{tabular}{|l|l|l|l|}
\hline Variable & $\begin{array}{l}\text { Associated } \\
\text { capability }\end{array}$ & Variable & $\begin{array}{l}\text { Associated } \\
\text { capability }\end{array}$ \\
\hline Slopes & & Geological risks & \\
\hline 1. Very low (VL) $0-5 \%$ & Very high (VH) & 1. Null (N) & Very high VH) \\
\hline 2. Low (L) 5-10\% & High (H) & 2. Low landslide (L) & Moderate (M) \\
\hline 3. Moderate (M) $10-15 \%$ & Moderate (M) & 3. Moderate landslide (M) & Low (L) \\
\hline 4. High (H) $15-45 \%$ & Moderate (M) & 4. High landslide (H) & Very low (VL) \\
\hline 5. Very high (VH) $>45 \%$ & Very low (VL) & $\begin{array}{l}\text { 5. Detachment of hillside } \\
\text { (D) }\end{array}$ & Very low (VL) \\
\hline Flood Risk & & $\begin{array}{l}\text { Accessibility to water } \\
\text { resources }\end{array}$ & \\
\hline 1. Null (0) & Very high (VH) & 1. Low (L) & Moderate (M) \\
\hline 2. Low (L) & Very low (VL) & 2. Moderate (M) & Moderate (M) \\
\hline 3. Moderate $(\mathrm{M})$ & Very low (VL) & 3. High (H) & Very high (VH) \\
\hline 4. High (H) & Very low (VL) & & \\
\hline
\end{tabular}

Each vector was categorized into capability levels for urban use as shown in Table 2, from very low to very high capability.

\subsection{Global vulnerability}

Land vulnerability to urban uses has been defined as the level of potential environmental impacts that may occur if a urban use is introduced in that zone [1].

To build global vulnerability vectorial layer five cartographic layers were considered: groundwater vulnerability to contamination, agrological capacity, cultural assets, vegetation and areas of interest subject to regulation. Table 3 details the source of these cartographic vectors. Groundwater vulnerability to contamination, agrological capacity and cultural assets were layers composed by single vectors, but the rest were multi-vector. Vegetation layer was a compilation of Strategic Forest Land, Forest Land and Agricultural and Urban Land. The Areas of Interest layer was a compilation of eight cartographic vectors were used: Natural Protected Areas, Natura 2000 Network, caves, wetlands, Public utility mountains, micro reserves, cattle routes and greenways.

The Green infrastructure vector was included in the process of planning by law on 2014 . Most of its components were already considered in the original methodology as cartographic vectors for vulnerability. Nowadays, the elements that are compulsory to consider in the planning methodology include the following: 1 . Areas with relevant environmental, cultural, agricultural and landscape values; 2. Critical areas whose transformation could involve environmental risks or costs for the community; and 3. Ecological corridors and functional connections that relate all the previous elements.

Each vector was categorized into vulnerability levels for urban use as shown in Table 4, from very low to very high vulnerability. 
Table 3: Source of cartographic vectors for vulnerability.

\begin{tabular}{|c|c|c|c|}
\hline $\begin{array}{l}\text { Cartographic } \\
\text { vector }\end{array}$ & $\begin{array}{l}\text { Download } \\
\text { server }\end{array}$ & $\begin{array}{l}\text { Creative institution of } \\
\text { the information }\end{array}$ & Observations \\
\hline $\begin{array}{l}\text { 1. Vulnerability } \\
\text { to groundwater } \\
\text { contamination }\end{array}$ & $\begin{array}{l}\text { Valencian } \\
\text { Spatial Data } \\
\text { Infrastructure }\end{array}$ & $\begin{array}{l}\text { Ministry of } \\
\text { Infrastructure, Territory } \\
\text { and Environment }\end{array}$ & $\begin{array}{l}\text { Vulnerability to the } \\
\text { contamination of groundwater } \\
\text { by urban activities in the } \\
\text { Valencian Community (year } \\
\text { 1995) }\end{array}$ \\
\hline $\begin{array}{l}\text { 2. Agrological } \\
\text { capacity }\end{array}$ & $\begin{array}{l}\text { Valencian } \\
\text { Spatial Data } \\
\text { Infrastructure }\end{array}$ & $\begin{array}{l}\text { Ministry of } \\
\text { Infrastructure, Territory } \\
\text { and Environment }\end{array}$ & $\begin{array}{l}\text { Land use capacity for the } \\
\text { Valencian Community (year } \\
\text { 1992) }\end{array}$ \\
\hline $\begin{array}{l}\text { 3. Cultural } \\
\text { assets }\end{array}$ & $\begin{array}{l}\text { Ministry of } \\
\text { Culture }\end{array}$ & Ministry of Culture & $\begin{array}{l}\text { General Inventory of } \\
\text { Valencian Cultural Heritage }\end{array}$ \\
\hline 4. Vegetation & $\begin{array}{l}\text { Valencian } \\
\text { Spatial Data } \\
\text { Infrastructure }\end{array}$ & $\begin{array}{l}\text { Organization and } \\
\text { Management } \\
\text { Techniques Service } \\
\text { Geological and Mining } \\
\text { Institute of Spain } \\
\end{array}$ & $\begin{array}{l}\text { Created from the layers: Use } \\
\text { of Agricultural land and } \\
\text { Urban land use }\end{array}$ \\
\hline & $\begin{array}{l}\text { Valencian } \\
\text { Spatial Data } \\
\text { Infrastructure }\end{array}$ & $\begin{array}{l}\text { Forest Management and } \\
\text { Management Service }\end{array}$ & $\begin{array}{l}\text { Strategic Forest Land Forest } \\
\text { Land }\end{array}$ \\
\hline \multirow{8}{*}{$\begin{array}{l}\text { 5. Areas of } \\
\text { Interest subject } \\
\text { to regulation }\end{array}$} & $\begin{array}{l}\text { Valencian } \\
\text { Spatial Data } \\
\text { Infrastructure }\end{array}$ & $\begin{array}{l}\text { Ministry for the } \\
\text { Ecological Transition }\end{array}$ & $\begin{array}{l}\text { Created from the layers: } \\
\text { Natural Protected Areas }\end{array}$ \\
\hline & $\begin{array}{l}\text { Ministry for } \\
\text { the } \\
\text { Ecological } \\
\text { Transition }\end{array}$ & $\begin{array}{l}\text { Ministry for the } \\
\text { Ecological Transition }\end{array}$ & $\begin{array}{l}\text { Natural Habitats of the Natura } \\
2000 \text { Network }\end{array}$ \\
\hline & $\begin{array}{l}\text { Valencian } \\
\text { Spatial Data } \\
\text { Infrastructure } \\
\end{array}$ & $\begin{array}{l}\text { Ministry for the } \\
\text { Ecological Transition } \\
\text { Forest Management and }\end{array}$ & Cavities \\
\hline & \multirow{5}{*}{$\begin{array}{l}\text { Valencian } \\
\text { Spatial Data } \\
\text { Infrastructure }\end{array}$} & Management Service & Public utility mountains \\
\hline & & $\begin{array}{l}\text { Ministry of Agriculture, } \\
\text { Environment, Climate } \\
\text { Change and Rural } \\
\text { Development }\end{array}$ & Wetlands \\
\hline & & Wildlife Service & $\begin{array}{l}\text { Micro reserves of flora and } \\
\text { fauna }\end{array}$ \\
\hline & & $\begin{array}{l}\text { Forest Management and } \\
\text { Management Service } \\
\end{array}$ & Cattle routes \\
\hline & & $\begin{array}{l}\text { Forest Management and } \\
\text { Management Service }\end{array}$ & Greenways \\
\hline $\begin{array}{l}\text { 6. Green } \\
\text { infrastructure }\end{array}$ & $\begin{array}{l}\text { Valencian } \\
\text { Spatial Data } \\
\text { Infrastructure }\end{array}$ & $\begin{array}{l}\text { Valencian Spatial Data } \\
\text { Infrastructure }\end{array}$ & $\begin{array}{l}\text { Includes other vulnerability } \\
\text { vectors }\end{array}$ \\
\hline
\end{tabular}


Table 4: Categorization of the variable "vulnerability to urban use".

\begin{tabular}{|l|l|l|l|}
\hline Variable & $\begin{array}{l}\text { Associated } \\
\text { vulnerability }\end{array}$ & Variable & $\begin{array}{l}\text { Associated } \\
\text { capacity }\end{array}$ \\
\hline $\begin{array}{l}\text { Vulnerability to } \\
\text { groundwater contamination }\end{array}$ & Agrological & \\
\hline 1. Very high (VH) & Hery high (VH) & 1. Very high (VH) & Very high VH) \\
\hline 2. High (H) & Moderate (M) & 3. High (H) & High (H) \\
\hline 3. Moderate (M) & Moderate (M) & 4. Low (L) & Moderate (M) \\
\hline 4. Low (L) & Low (L) & 5. Very low (L) & Very low (VL) \\
\hline 5. Very low (L) & $\begin{array}{l}\text { Areas of interest } \\
\text { subject to } \\
\text { regulation }\end{array}$ & \\
\hline Vegetation & $\begin{array}{l}\text { 1. Environment of } \\
\text { Interest }\end{array}$ & Very high VH) \\
\hline $\begin{array}{l}\text { 1. Forestry with protected } \\
\text { species (P) }\end{array}$ & Very high (VH) & 2. The rest & Very low (VL) \\
\hline $\begin{array}{l}\text { 2. Forestry without protected } \\
\text { species (A) }\end{array}$ & High (H) & Cultural assets & \\
\hline 3. Agricultural area & Low (L) & 1. Assets cultural & Very high VH) \\
\hline $\begin{array}{l}\text { 4. Urban areas and } \\
\text { infrastructure }\end{array}$ & Very low (VL) & 2. The rest & Very low (VL) \\
\hline
\end{tabular}

\subsection{Global aptitude}

Aptitude is the synthesis of capability and vulnerability [1]. Global aptitude layer was obtained from the combination of global capability and global vulnerability layers as shown in Table 5.

Table 5: Global aptitude.

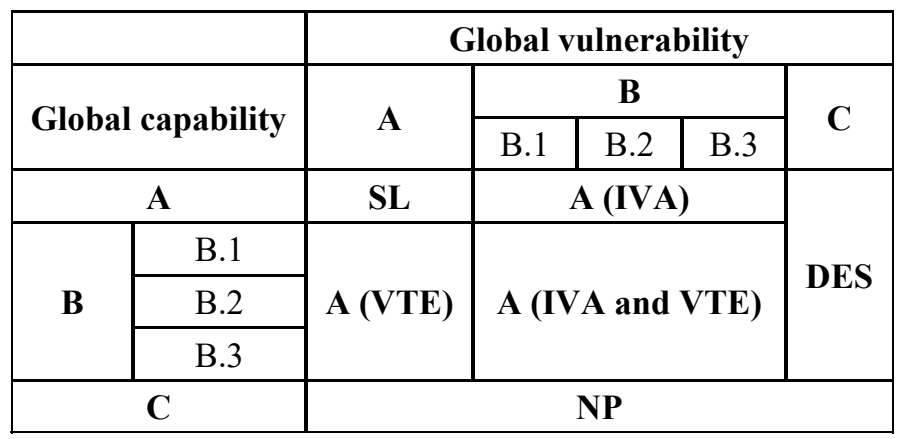




\section{RESULTS AND DISCUSSION}

\subsection{Global capability map}

Three situations can happen as derived from Table 5:

- Situation A (A1, A2): capability does not present technical or economical limitation to urbanization.

- Situation B (B1, B2, B3): capability present limitations that can be overcome.

- Situation $\mathrm{C}(\mathrm{C} 1, \mathrm{C} 2)$ : capability present limitations to urbanize the area and technical correction is impossible, too much costly or may cause potential catastrophic situations.

Global capability was built with four cartographic variables, and each variable can be in situation A, B or C for a specific zone. So, in the capability map, we found zones without technical limitations to urbanize (all variables are in situation A), zones which can overcome technical limitations (at least one variable in situation B but no variable in situation C) and zones with potential catastrophic risks or too much costly to urbanize (at least one variable in situation C).

Fig. 2 shows the global capability map for La Safor region, where all the above described situations can be found in different zones.

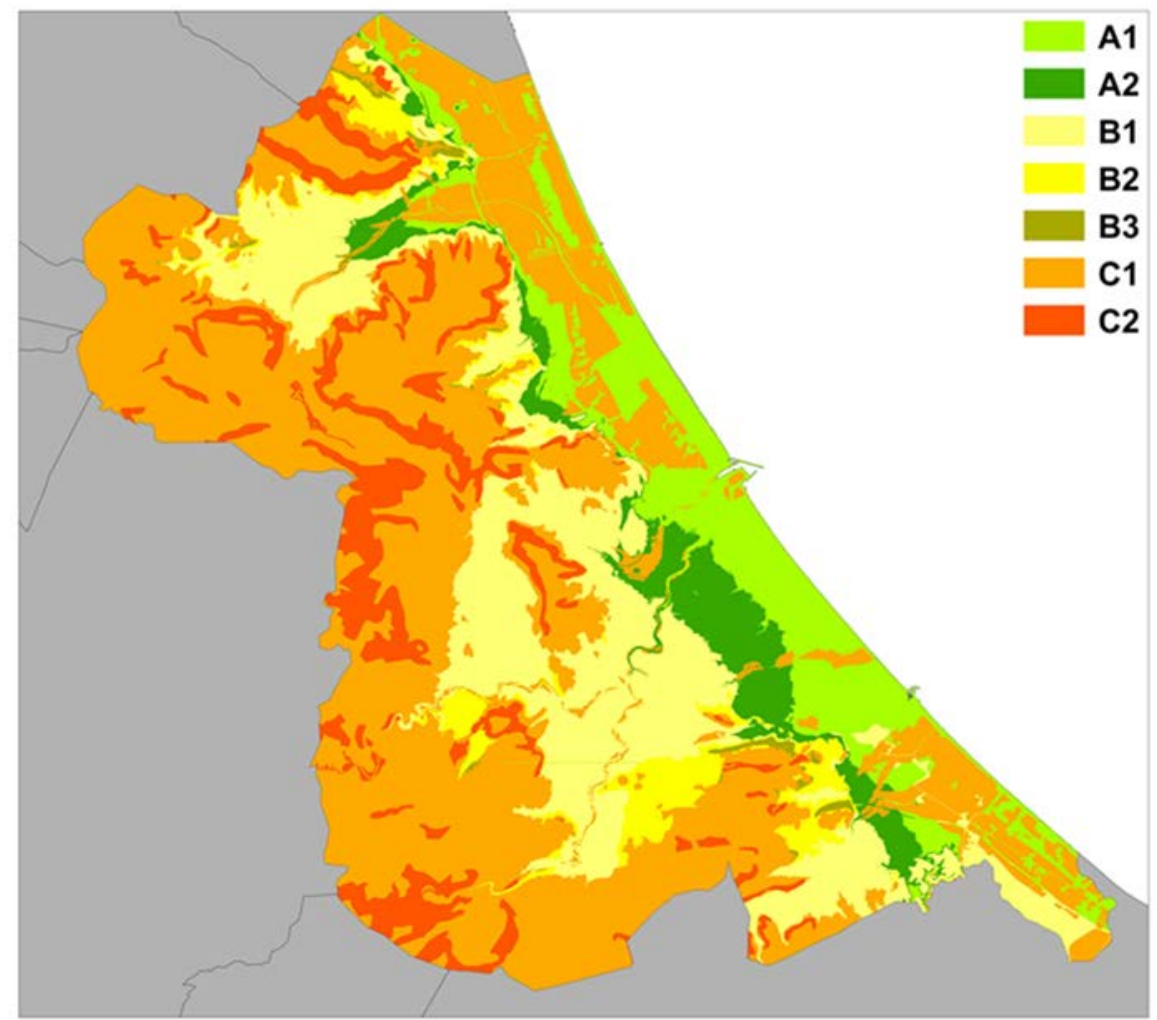

Figure 2: Capability map of La Safor (Valencia, Spain). 


\subsection{Global vulnerability map}

Three situations can happen:

- Situation A (A1, A2): there are no environmental constraints for urbanization.

- Situation B (B1, B2, B3): the urbanization process can alter environmental values, but corrective measures can be implemented.

- Situation $\mathrm{C}(\mathrm{C} 1, \mathrm{C} 2)$ : the urbanization process can cause irreversible damages to environmental values.

Fig. 3 shows the global vulnerability map for La Safor region, where all the above described situations can be found in different zones.

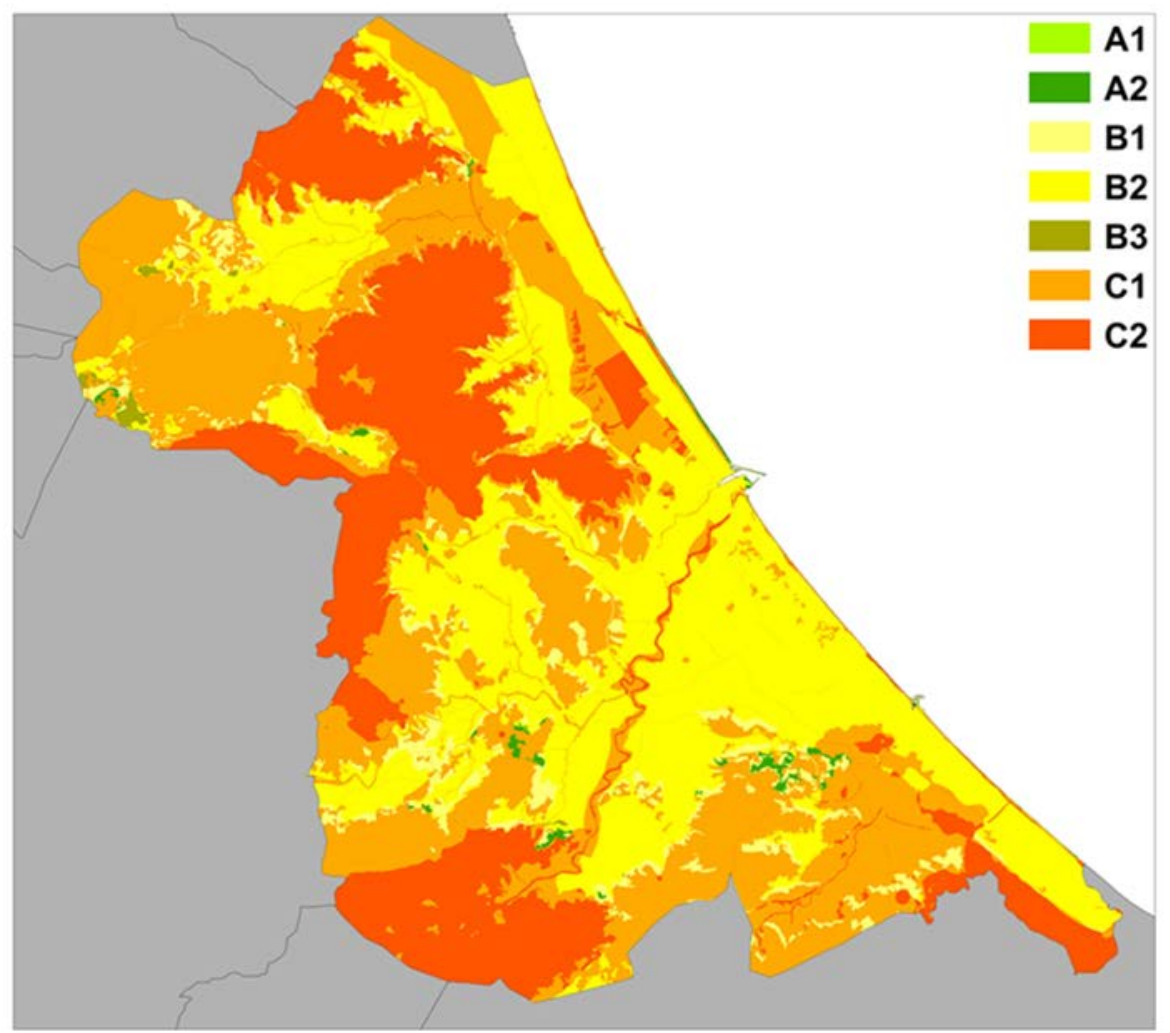

Figure 3: Vulnerability map of La Safor (Valencia, Spain).

\subsection{Global aptitude map}

The zones with better aptitude are those with higher capacity and minimal vulnerability. The possible situations are:

- SL: Without Limitations (in Spanish "Sin Limitación").

- A (VTE): Permitted uses after favourable technical feasibility report. 
- A (IVA): Permitted uses after favourable environmental feasibility report.

- A (IVA and VTE): Permitted uses after favourable report of technical feasibility and environmental feasibility.

- DES: Inadvisable use due to incompatibility with sustainable economic development.

- NP: In general, prohibited uses.

Fig. 4 shows the global aptitude map for La Safor region, where all the above described situations can be found in different zones.

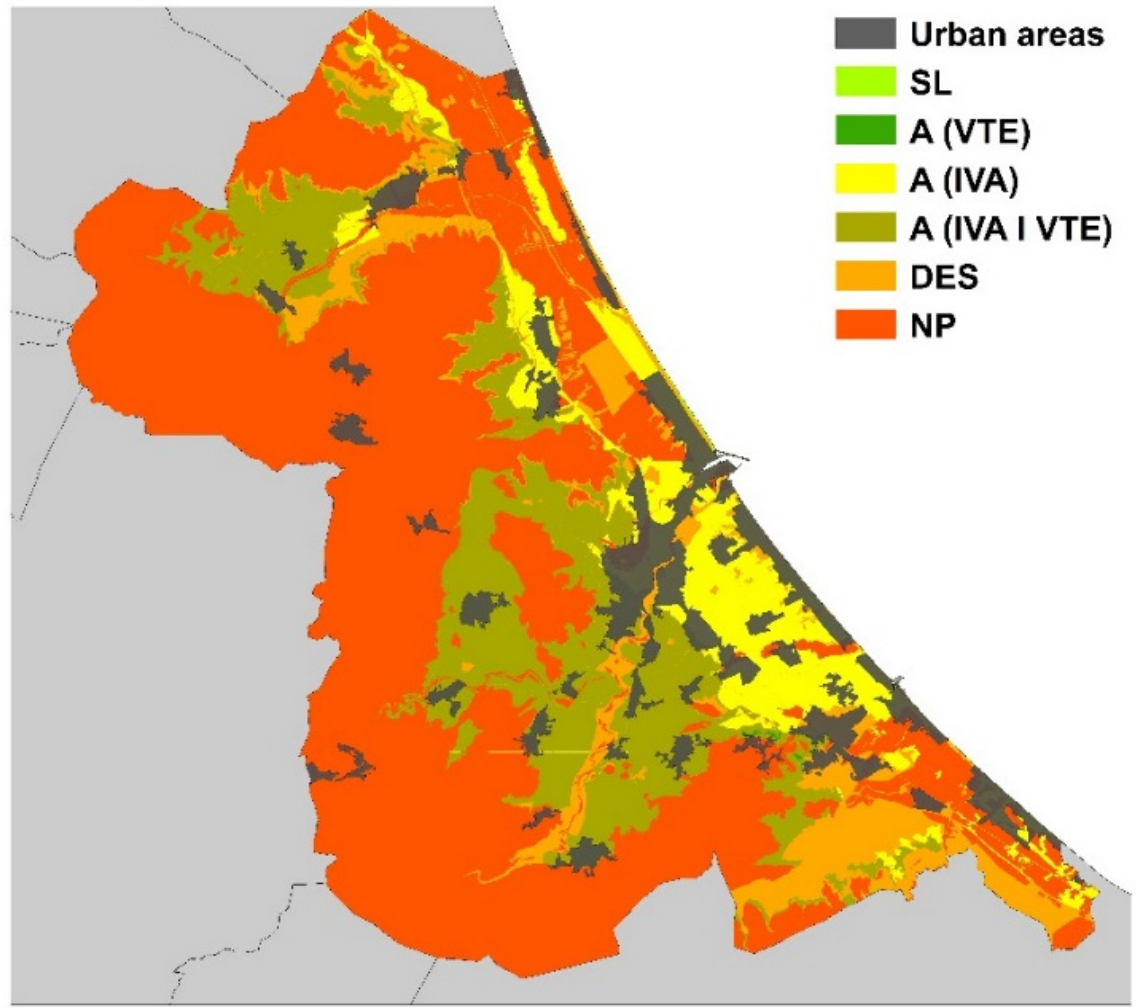

Figure 4: Aptitude map of La Safor (Valencia, Spain). Grey areas are already consolidated urban areas.

Table 6 summarizes the aptitude data for the six situations described. $56 \%$ of La Safor region land, which accounts for $251.8 \mathrm{~km}^{2}$, is classified as prohibited for general urban use due to low capability and high vulnerability, and $13 \%$ is classified as inadvisable. $30 \%$ of the territory presents technical or environmental constraints that makes necessary their analysis before planning new urban developments.

As shown in Table 6, existing urban areas were mostly developed in areas characterized by technical or environmental constraints (e.g. soils with high agrological capacity, groundwater vulnerability, etc.). However, there exist several urban zones located in areas where they should not be because of their characteristics. 
Table 6: Aptitude statistics in La Safor.

\begin{tabular}{|l|c|c|}
\hline & Area $\left(\mathrm{km}^{2}\right)$ & $\%$ \\
\hline SL & 0.4 & 0.1 \\
\hline A (IVA) & 53.3 & 11.9 \\
\hline A (VTE) & 0.5 & 0.1 \\
\hline A (IVA and VTE) & 81.4 & 18.2 \\
\hline DES & 60.1 & 13.4 \\
\hline NP & 251.8 & 56.3 \\
\hline & $\mathbf{4 4 7 . 4}$ & $\mathbf{1 0 0}$ \\
\hline
\end{tabular}

\section{CONCLUSION}

The methodology presented here can be a very useful tool at the stage of strategic planning to decide the better zones for urban development, but also can be used to understand the effects of natural risks on already developed urban areas.

Strategic environmental assessment of plans has included among its premises the need to consider the effects of the plans evaluated on climate change and vice versa [7], [8]. In this methodology, the most updated cartography has been used. But there is a need to review some cartographic vectors that could be influenced by climate change, such as accessibility to water resources or flooding risk. It is recommended to create different scenarios under the climate change premises to develop a sustainable planning.

\section{ACKNOWLEDGEMENT}

The authors wish to thank the department of Urban Planning, Universitat Politècnica de València, for the conference assistance grant.

\section{REFERENCES}

[1] Miralles-i-Garcia, J.L. \& Altur-Grau, V.J., Updated method of aptitude to sustainable urban development for including green infrastructure. International Journal of Sustainable Development and Planning. 11(6), pp. 970-979, 2016.

DOI: $10.2495 /$ SDP-V11-N6-970-979.

[2] Constitución Española (Spanish Constitution), "BOE" num. 311, 29 December 1978, pp. 29313-29424 (112 pp.). www.boe.es/eli/es/c/1978/12/27/(1). Accessed on: 12 Mar. 2019.

[3] Ley Orgánica 5/1982, de 1 de julio, de Estatuto de Autonomía de la Comunidad Valenciana/ (Law 5/1982 of 1 July on Statute of Autonomy of the Valencian Community). www.boe.es/eli/es/lo/1982/07/01/5/con. Accessed on: 12 Mar. 2019.

[4] Ley 5/2014, de 25 de julio, de Ordenación del Territorio, Urbanismo y Paisaje, de la Comunitat Valenciana/ (Law 5/2014 of 25 July on Territorial Planning, Town Planning and Landscape, of the Valencian Community). www.boe.es/eli/es-vc/1/2014/07/25/5/con. Accessed on: 12 Mar. 2019.

[5] Directive 2007/2/EC of the European Parliament and of the Council of 14 March 2007 establishing an Infrastructure for Spatial Information in the European Community (Inspire). http://data.europa.eu/eli/dir/2007/2/oj. Accessed on: 12 Mar. 2019. 
[6] Ley 14/2010, de 5 de julio, sobre las infraestructuras y los servicios de información geográfica en España/ (Law 14/2010 of 5 July on Infrastructures and Geographic Information Services in Spain). www.boe.es/eli/es/1/2010/07/05/14. Accessed on: 12 Mar. 2019.

[7] Ley 21/2013, de 9 de diciembre, de evaluación ambiental/ (Law 21/2013 of 9 December on Environmental Evaluation). www.boe.es/eli/es/1/2013/12/09/21/con. Accessed on: 12 Mar. 2019.

[8] Directive 2001/42/EC - Strategic Environmental Assessment Directive (SEA). https://eur-lex.europa.eu/legal-content/ES/TXT/?uri=LEGISSUM:128036. Accessed on: 12 Mar. 2019. 